\title{
The challenges of Rural Students in Vietnam towards higher education
}

\author{
Lo Van Pang
}

${ }^{1}$ University of Foreign Language Studies, The University of Da Nang, Vietnam

*Corresponding author's email: lvpang@ufl.udn.vn

*(D) https://orcid.org/0000-0002-4200-0266

doi https://doi.org/10.54855/ijte.222114

\begin{tabular}{ll} 
Received: 16/12/2021 & Revision: 20/01/2022 Accepted: 26/01/2022 \\
\hline & \multicolumn{1}{c}{ ABSTRACT } \\
\hline & $\begin{array}{l}\text { This study aims to explore the challenges and difficulties that rural } \\
\text { students experience when they transition to Higher Education in } \\
\text { Vietnam to pursue their higher studies. This study was carried out at } \\
\text { a local University in Vietnam. It is a qualitative research study, and } \\
\text { data were collected through semi-structured interviews with 10 } \\
\text { participants. The participants were all first-year students, including } \\
\text { males and females. The interviews involved answering semi- } \\
\text { structured questions. Multiple interviews were carried out with each } \\
\text { participant. The study discovered that rural students experience } \\
\text { many difficulties at university in relation to their relationships with } \\
\text { teachers and peers, getting support, overcoming prejudice, online } \\
\text { Student, higher } \\
\text { education, } \\
\text { difficulties, education } \\
\text { experiences }\end{array}$ \\
learning, and economic hardship.
\end{tabular}

\section{Introduction}

Education is a driving force for economic and social development. In developing countries like Vietnam, education underpins future national prosperity, and governments have made major efforts over recent decades to enhance the country's educational performance. For many rural and economically disadvantaged students, going to university is considered the only way to get out of their difficult situation to achieve a better life (Pang, 2017). However, going to university is not plain sailing for these students. They have to leave their home and family to move to a big city to pursue their study. In their study, they meet many difficulties, and many students end up leaving school when they fail to overcome these challenges (Gil, Antelm-Lanzat, CacheiroGonzalez, Perez-Navio, 2019).

Vietnam is primarily an agricultural country, and a large proportion of the population lives in rural regions (Office, 2020). Many are farm-dependent and have no other income other than what their farm provides (Tuyen et al., 2015). Many who live in rural and mountainous communities are categorized as poor and below-poor families. Poor households, on average, earn around $\$ 90$ per month (GSO, 2021). In addition, transport is a big issue in mountainous 
areas, especially during the rainy seasons (Khánh \& Kiên, 2021).

Moving from high school to university is a major turning point in a student's life. For each student, the first year is often the most difficult period because students' have to change their living environment as well as to start an independent life with new methods and ways of learning (Long, 2007). It is a difficult time even for urban students who are from large cities and town centers. For students from rural and remote areas, it is even more difficult. So as to help the rural students to overcome their difficulties and integrate well with the new learning environment, there is a need for a high level of collaboration between teachers, universities, families, and students. Only by doing this are the goals of the Vietnam government going to be achieved.

\section{Literature review}

\section{Students have basic human needs}

Students have basic needs for safety, food, comfort, acceptance, regard, and protection. When basic human needs are unmet, this obstructs learning, motivation, attention, and engagement (Maslow, 1987). As a human being, each person needs sensual enjoyment, affiliation, selfregard, safety, order, or understanding (Streeten, 1971). Betoret and Artiga (2011) state that if students' psychological satisfaction need is met, they tend to be more confident in their class and have better learning outcomes at school (Betoret \& Artiga, 2011).

The need to belong is a basic human need (Baumeister \& Leary, 1995). A sense of belonging results from the development of positive classroom relationships. Negative relationships with peers pose a threat to one's sense of safety. Bullying, rejection, social exclusion, discrimination, abuse, and neglect undermine a student's sense of belonging and safety which are critically important for their social and academic functioning. Loneliness, social discrimination, isolation, and discrimination are serious challenges that need to be addressed if students are to feel safe, have a sense of belonging, and be successful students (Maslow, 1987; Buhs et al., 2016; Murray-Harvey \& Slee, 2010).

\section{Learning is not just a solitary activity.}

It is shaped by relationships, circumstances, and situational factors. Learning is not separate from peoples' personal and social lives. People do not live their lives as solitary individuals, and their lives are linked and interdependent (Feinstein et al., 2008). In this study, the researcher takes a socio-ecological approach to study the challenges experienced by participants (Bronfenbrenner, 1979, 1986; Fitzgibbon et al., 2014). A socio-ecological approach will study student behavior from levels, ranging from the student as an individual to the student as a member of a family to the student as a member of a peer group to the student as a member of a class group and school community to the student as a member of a neighborhood. These levels

are assumed to be interdependent and to influence each other mutually. So as to understand a person, the factors such as culture, effects of peer group, school-to-work transitions, teacher- 
student relationship, demand, status, and morale need considering (Davies, 2012).

Relationships with teachers, peers, friends, partners, and family play a key role in students' lives and learning.

Relationships can provide students with safety, care, support, companionship, fun, and intimacy, but they do not always do so ( Baafi, 2020; Duchesne \& McMaugh, 2016). People's basic human needs are met through their relationships. If their basic needs are not met, then this negatively impacts their learning and lives. Relationships can be assets and liabilities (Giliker, 2010). Negative relationships can be stressful, painful, and a source of much unhappiness (Krause et al., 2010). Relationships are resources and key determinants of our well-being and mental health. Relationships are an important safety net at times of difficulty (Murray-Harvey, 2010).

\section{The teacher-student relationship is of central importance to teaching and learning.}

Positive teacher-student relationships are based upon two-way open communication, mutual liking, support, encouragement, responsiveness, and self-disclosure (Baafi, 2020). Effective communication and collaboration are at the heart of teaching and learning. If teachers are perceived as unapproachable or if students engage in self-silencing, this seriously undermines teacher-student collaboration and student learning (Runions et al., 2021). Negative relationships with teachers can severely disrupt student learning, motivation, sense of well-being, and working cooperatively with others (Murray-Harvey \& Slee, 2010).

\section{Friends provide important benefits and advantages for students}

Friends perform important roles as confidants, companions, supporters and shield each other from social difficulties (McGrath \& Noble, 2010). They can also provide help and encouragement in coping with challenges. Having friends is an antidote to loneliness and social isolation. Friends are necessities, not luxuries.

\section{Social support helps students cope with challenges and difficulties.}

Social support plays a crucial role in students and their learning outcomes at school (Balzer Carr \& London, 2019). Gao and colleagues studied the role of support with students in China and affirmed that the students who receive support from friends, teachers, and family have higher achievement at school than the others (Gao et al., 2021). Lack of social support can result in the student's not coping, procrastination, and dropping out of education. Social support includes emotional validation as well as practical support (Ertel et al., 2009; Balzer Carr \& London, 2019; Runions et al., 2021).

\section{Self-efficacy beliefs shape a student's motivation and perseverance when there are challenges or difficulties.}

Students who do not believe they cannot perform tasks are likely to avoid attempting these tasks and to give up when they experience difficulties (Bandura, 1977, 1997, 1986). When a student loses his or her self-confidence, they will lose motivation in learning. Thus this type of student 
often chooses to avoid their problems in learning instead of finding a solution for them (Pang, 2017). In contrast, students who have strong self-efficacy tend to seek help from their teachers or peers with their learning difficulties and be successful at school (Gao et al., 2021).

Choice of coping strategies influences the outcomes and how successfully they address difficulties.

Coping strategies such as help-seeking, self-silencing, procrastination, avoidance coping, and communal coping influence the learning outcomes (Lazarus \& Folkman, 1984; Murray-Harvey, 2010). The academic achievement and help-seeking frequency are significantly correlated as their problems are solved in time (Mahasneh et al., 2012). Positive, projective, denial, and noncoping are popular among Turkish students (Mete \& SubasiI, 2020). Positive students often try to solve their problems by seeking help from the other, while denial or non-coping tend to avoid their learning issues.

\section{Social and physical resources influence student learning}

Poverty differentially exposes people to stressors, problems, and challenges (Hobfoll, 2002). Giacchino-Baker (2007) states that 'economic conditions and inequities continue to be the primary causes of education gaps in Vietnam' (p. 170) and that 'socioeconomic status still affects attitudes toward rural students' abilities' (Giacchino-Baker, 2007, p.173). Unequal access to technology means some students are discriminated against when they are required to learn online.

When referring to rural students, this means they are-students who come from rural families and rural areas. "Rural refers to open areas of a country with a small number of settlements, these areas are characterized by a dependence on agriculture and natural resources; high prevalence of poverty, isolation, and marginality; neglect by policymakers; and lower human development" (Dasgupta et al., 2017. p. 618). Rural families are often poor and live in remote regions (Tuyen et al., 2015), where economic hardship results in practical difficulties for students and their parents. Koricich et al. (2018) stated that rural students have fewer opportunities to attend prestigious or highly competitive schools, especially in higher education, because of their socioeconomic status (Koricich et al., 2018).

\section{Research Questions}

To fulfill the purpose of the study, the survey was seeking to answer the following research questions:

What challenges do rural students in Vietnam experience when they transition to studying at university? 


\section{Methods}

\section{University Setting \& Participants}

Participants were from the University of Foreign Language Studies (UFLS) in Da Nang, Vietnam. The UFLS's mission is to train the central and highland provinces' language skills and labor force (Phuc, 2021). Da Nang is a city that is a central hub for tourism, education, and economic activity.

Ten student participants were chosen randomly and were then invited to participate in this study. All participants were in their first year of study and came from rural regions in Vietnam. Participation in this study was voluntary and based on informed consent and the maintenance of confidentiality and anonymity. 4 male and six female students volunteered to be participants. The author conducted the interviews.

The interviews used in this study explored the areas highlighted in the above assumptions. Questions asked focused on such issues as the teacher-student relationship, life challenges, coping strategies used, experiences of social support, the nature of peer relationships, experiences of negative relationships, unmet needs, etc.

\section{Design of the Study}

This qualitative study used a case study methodology as described by Yin (2003) and Stake (2005). In this study, ten student case studies were developed based on interview data from the students. Each of the 10 case studies focused on the challenges and difficulties students' experienced during their study at university.

\section{Data collection}

Multiple one-on-one interviews were held with each of the student participants. Students participants were interviewed on a number of occasions to assist in the development of trust and rapport (Seidman, 2013). With participants' permission, interviews were recorded on a digital recorder.

Interview questions were semi-structured using both open-ended and closed questions (Burgess-Limerick \& Burgess-Limerick, 1998). Each interview lasted 30 to 40 minutes and was conducted in a room at the university that provided visual and auditory privacy. Member checking was used to ensure the credibility of the data collected.

\section{Data analysis}

Interview data were partially transcribed and typed into Microsoft Word files. Because of the number of interviews carried out, the decision was taken to only partially transcribe interviews to make the task more manageable within the study's time constraints. Ten separate case studies were developed by triangulating interview data from the students' interviews (Yin, 2003). After developing the ten case studies, commonalities and differences between them were identified and analyzed in terms of learning difficulties. 


\section{Findings}

\section{The Teacher-Student Relationship}

All study participants expressed the belief that their teachers were unapproachable. As a result of this, participants engaged in self-silencing if they had difficulties, and teachers gained little understanding of their students' ongoing difficulties and concerns. These students generally struggled on their own to resolve any difficulties. This means their teachers were to some extent blind and deaf to their difficulties.

"Our teachers are very busy with their teaching so they don't care much about our difficulties in learning. They just come to class when the lesson starts and leave immediately after lesson. We have many problems want to ask our teachers but as you can see, we have no opportunities. I have to resolve my problems by myself" (Mai).

A healthy teacher-student relationship is based upon open two-way communication, encouragement of and valuing help-seeking, collaborative problem solving, and providing support when needed. Improving the teacher-student relationship would greatly assist these rural students' learning and collaboration.

\section{Peer Relationships}

9 of 10 participants saw few opportunities to build friendships or positive relationships with peers either in or of the classroom. There was little opportunity for group work or participation in community projects, peer support programs, or sports teams.

"In class, I often feel lonely as there is no one else coming from my community. The other classmates come from the other places and they have already known each other. I find it very difficult to make friend. They tend to play and talk to each other and of course I am ignored. I feel I am inferior in group work or discussion in the class" (Nam).

There were very limited social or sporting activities they could participate in. While the university occasionally organized sports tournaments, participants usually were expected to have expertise in the sports involved. Because they usually came from districts where they did not have an opportunity to develop expertise in these sports, rural students found themselves excluded from such activities.

Participants generally felt inferior and second-class citizens to their urban-based peers. They recognized that they had not had the same opportunities or the same socioeconomic advantages as their city-based peers. Their parents were less well educated, they had fewer amenities at home, and their rural schools were more poorly resourced.

In order to avoid attracting negative attention, all of the 10 participants talked about deliberately keeping quiet and silent in class and seeking to avoid making mistakes, which others can interpret as evidence that they are ignorant or academically inferior. Study participants generally felt lonely, isolated, and to some degree, social outcasts. This posed a special challenge for them, robbing them of confidence and self-esteem. 
From interviews with their teachers, this researcher found that teachers did not see it as part of their role to build and encourage peer relationships or to reduce the prejudice or stigma experienced by rural students.

Sense of Belonging

$80 \%$ of participants did not feel a sense of belonging. A sense of belonging is about being valued and included and feeling one matters. Belonging to a group is important. The only group they felt they might belong to one was an outcast group. The research shows that lack of school belongingness and connectedness often predicts depression.

"I often feel lonely at school. I am too different from the others in my class. They have stylish clothes and hairstyles. My thinking and language are different from their as well" (Loan).

\section{Support Provided/Available}

When their teachers cannot or do not support them with difficulties or concerns, they have to sort out problems by themselves. All of the participants could not rely on their family or friends to help them for a variety of reasons, including lack of friends, distance from home, and their parents' limited education. Rural students at university live some distance from their parents and home communities.

Sense of Self-Efficacy

All of the studied participants expressed a low sense of academic self-efficacy. They were struggling with the work and had self-esteem.

"I think am not good at learning at all when I participate in the class. My classmates are too smart and their ideas are very brilliant. After hearing their words, all the ideas disappear from my head" (Ngoc).

\section{Student Coping Strategies}

All participants were limited in their choice of coping strategies. Given their perception of their teachers as unapproachable and the lack of other sources of support, they were left with struggling on their own, giving up, making out they were coping (self-silencing), and avoidance coping. Study participants said they were fearful of some of their teachers, which was another reason they did not try to ask their teachers for help. Another reason might have been not knowing what help to ask for. If one does not understand something, it can be hard to ask for help in relation to it.

\section{Sense of Inferiority}

Seven of 10 participants did express a sense of inferiority attached to the fact that they were rural students. They perceived themselves as being ignored or looked down up by their teachers and urban peers. No one at the university was seen as taking any steps to address this prejudice or discrimination. They perceived themselves as socially discriminated and considered less academically and socially able. 
Teachers were not seen as taking any steps to get to know them as people or to listen to their voices. So rural students perceived themselves as voiceless and, to some extent, social outcasts. In working with marginalized students, listening to them requires not only open eyes and ears but open hearts and minds and putting one's beliefs on hold. Without undertaking this kind of listening, change is unlikely.

\section{Learning Online}

When COVID-19 resulted in teaching and learning online, this added to the difficulties experienced by study participants. All of the 10 participants did not have the technology, technological knowledge, or support to get the most out of online learning. Having access to mobile phones with their very small screens and unreliable and unstable internet connections in rural areas severely disadvantaged rural students engaged in online learning. Some learning platforms are not suitable for use with a mobile phone. Communicating clearly and clarifying instructions online poses further problems. Access to help and support is not any easier in an online context. It takes teachers and students considerable time to be competent in using technology in language teaching and learning. Some platforms such as LMS, Teams, or Exam are sophisticated and require much time for both teachers and students to learn.

\section{Economic Hardship}

All participants in this study came from low-income families where their main income was from farming. Farming activities depend upon the weather, and weather conditions fluctuate markedly. This means family incomes vary from one year to the next. Participants said that they are anxious and stressed whenever school fees are due if the fees cannot be paid.

As a requirement for graduation, the final year students are required to have achieved a $\mathrm{C} 1$ certificate in English proficiency or 7.0 IELTS. In order to gain this certificate, it is necessary to participate in extra lessons. Families cannot always afford for their children to attend these lessons. For these students, extra classes at language centers are too expensive for them. Family economic hardship puts a lot of stress and pressure on rural students (Luong \& Nieke, 2013).

\section{Discussion}

When studying away from home, students face many challenges in their learning as well as in their daily life (Nghiem et al., 2021). The challenges experienced by study participants are many and varied, but there is not a common agreement or understanding about what the problems are or what needs to be done about them. For example, improving the teacher-student relationship is not, this may be believed that generally seen as the major problem, nor is addressing the loneliness, sense of isolation, and perceived inferiority of rural students. Students' relationship has been mentioned as one of the main learning and teaching issues that need to be taken into consideration by teachers and educators (Maslow, 1987; Baafi, 2020).

There is probably more general agreement about the need to provide more academic support for students with learning and academic difficulties (Linh \& Ngo, 2021). But focusing simply 
on providing more academic support will not address the other challenges identified in this study, such as the need to provide additional social and emotional support.

It is suspected one of the problems in recognizing the need to improve the teacher-student relationship is that many teachers think that when students are well-behaving, they have a good relationship with them, even when the student is generally silent (i.e., self-silencing) (Tu \& $\mathrm{Chu}, 2020)$. Behavioral compliance by itself is not evidence of a positive relationship. It is believed such thinking needs to change. We need to consider positive teacher-student relationships as based upon the openness of communication, mutual liking, collaborative assessment and problem solving, provision of encouragement, and mutual respect.

Building positive teacher-student relationships and peer relationships needs to be acknowledged and recognized as a key educational goal for all educators (Baafi, 2020). It needs to be recognized that a student's basic human needs are met primarily through having positive relationships with their teachers and classmates. Positive relationships provide people with important benefits and advantages that enhance motivation, learning, and well-being. Two key benefits of positive relationships are companionship and social support. At times of difficulty, positive relationships provide an extremely important safety net.

\section{Limitations}

This research was a pilot study, and there are a number of limitations. It is only a small sample and does not necessarily reflect the perceptions and experiences of other rural students in Vietnam. Participants in this study included only first-year students and did not include students from other year levels or from across all the different rural regions in Vietnam. It also did not assess the learning or cognitive needs of participants.

While this was only a pilot study, it has identified a number of critical educational issues for this particular group of rural participants. Further research is needed, and it is important to determine the generality of these findings for rural students in Higher Education in Vietnam and in other countries.

\section{Conclusion}

When rural students perceive that they do not socially belong at an urban-based University, and they perceive their teachers and lecturers as unapproachable and unwilling to help them; when they engage in self-silencing as a way of coping or surviving; when their basic human needs are unheard, unrecognized and unmet; when they believe they are socially inferior and disconnected from the majority of their classmates, and they feel lonely and lacking in selfefficacy and social support; when they only have access to inferior technology that is needed to participate effectively in online learning, then these conditions and beliefs negatively impact upon their motivation, participation and achievement, and their sense of well-being and mental health. 
As educators of rural students, we need to listen carefully and sensitively to the voices of our students - to listen to their feelings, needs and perceptions. We need to work collaboratively with our students to meet their basic human needs better and help overcome their challenges and difficulties. In addition, it is necessary to replace self-silencing and a sense of loneliness and isolation with a truly collaborative two-way partnership that promotes the development of positive relationships, personal growth, and self-efficacy.

\section{References}

Baafi, R. K. A. (2020). Teacher-Student Relationship and Student Learning Outcomes in Senior Public. European Journal of Education Studies, 6(12), 147-161. https://doi.org/10.5281/zenodo.3676476

Balzer Carr, B., \& London, R. A. (2019). The role of learning support services in university students' educational outcomes. Journal of College Student Retention: Research, Theory \& Practice, 21(1), 78-104.

Bandura, A. (1977). Social Learning Theory. Prentice-Hall.

Bandura, A. (1986). Social Foundations of Thought and Action: A Social Cognitive Theory. N.J.: Prentice-Hall.

Bandura, A. (1997). Self-efficacy: the exercise of control. W.H. Freeman.

Baumeister, R. F., \& Leary, M. R. (1995). The need to belong: desire for interpersonal attachments as a fundamental human motivation. Psychological Bulletin, 117(3), 497-529.

Betoret, F. D., \& Artiga, A. G. (2011). The relationship among student basic need satisfaction, approaches to learning, reporting of avoidance strategies and achievement. Electronic Journal of Research in Educational Psychology, 9(2), 463-496.

Bronfenbrenner, U. (1979). The ecology of human development: experiments by nature and design. Havard University Press.

Bronfenbrenner, U. (1986). Ecology of the family as a context for human development: research perspectives. Developmental Psychology, 22, 723-742.

Buhs, E. S., Ladd, G. W., \& Herald, S. L. (2016). Peer exclusion and victimization: Processes that mediate the relation between peer group rejection and children's classroom engagement and achievement? Journal of Educational Psychology, 98(1), 1-13.

Burgess-Limerick, T., \& Burgess-Limerick, R. (1998). Conversational interviews and multicase research in psychology. Australian Journal of Psychology, 50(2), 63-70.

Dasgupta, P., Morton, J. F., Dodman, D., Karapinar, B., Meza, F., Rivera-Ferre, M. G., Sarr, A. T., Vincent, K. E., Carr, E. R., Raholijao, N., \& Broecker, H. (2015). Rural areas. In Climate Change 2014 Impacts, Adaptation and Vulnerability: Part A: Global and Sectoral Aspects (Issue January). https://doi.org/10.1017/CBO9781107415379.014 
Davies, B. (2012). The sociology of education. Educational Theory and Its Foundation Disciplines, 142(January), 100-152. https://doi.org/10.4324/9780203138564

Duchesne, S., \& McMaugh, A. (2016). Educational psychology for learning and teaching (5th ed.). Cengage Learning.

Ertel, K. A., Glymour, M., \& Berkman, L. F. (2009). Social networks and health: A life-course perspective integrating observational and experimental evidence. Journal of Social and Personal Relationships, 26(1), 73-92.

Feinstein, L., Budge, D., Vorhaus, J., \& Duckworth, K. (2008). The social and personal benefits of learning : A summary of key research findings (Issue May).

Fitzgibbon, M. L., Kong, A., \& Tussing-Humphreys, L. (2014). Understanding population health from multi-level and community-based models. In K. A. Riekert, J. K. Ockene, \& L. Pbert (Eds.), The handbook of health behavior change (4th ed., pp. 27-45).

Gao, H., Ou, Y., Zhang, Z., Ni, M., Zhou, X., \& Liao, L. (2021). The Relationship Between Family Support and e-Learning Engagement in College Students: The Mediating Role of e-Learning Normative Consciousness and Behaviors and Self-Efficacy. Frontiers in Psychology, 12(February). https://doi.org/10.3389/fpsyg.2021.573779

Giacchino-Baker, R. (2007). Educating ethnic minorities in Vietnam: policies and perspectives. Kappa Delta Pi Record, 43(4), 168-173.

Gil, A. J., Antelm-Lanzat, A. M., Cacheiro-González, M. L., \& Pérez-Navío, E. (2019). School dropout factors: a teacher and school manager perspective. Educational Studies, 45(6), 756-770. https://doi.org/10.1080/03055698.2018.1516632

Giliker, P. (2010). Other relationships giving rise to liability. In C. S. in I. and C. Law (Ed.), Vicarious Liability in Tort: A Comparative Perspective (pp. 101-144). Cambridge University Press. https://doi.org/10.1017/CBO9780511779008.006

GSO. (2021). Thông cáo báo chí về kết quả khảo sát mức sống năm 2020. Tổng Cục Thống Kê. https://www.gso.gov.vn/du-lieu-va-so-lieu-thong-ke/2021/07/thong-cao-bao-chi-ve-ketqua-khao-sat-muc-song-dan-cu-nam-2020/

Hobfoll, S. E. (2002). Social and psychological resources and adaptation. Review of General Psychology, 6(4), 307-324.

Khánh, H., \& Kiên, T. (2021). Phát triển đuờng giao thông nông thôn là nền tảng cho sư phát triển kinh tế - xã hội bền vùng. Cổng Thông Tin Điện Tử Huyện Lâm Bình. http://lambinh.tuyenquang.gov.vn/tin-tuc-su-kien/kinh-te-xa-hoi/phat-trien-duong-giaothong-nong-thon-la-nen-tang-cho-su-phat-trien-kinh-te-xa-hoi-ben-vung-3701.html

Koricich, A., Chen, X., \& Hughes, R. P. (2018). Understanding the effects of rurality and socioeconomic status on college attendance and institutional choice in the United States. The Review of Higher Education, 41, 281-305. 
Lazarus, R. S., \& Folkman, S. (1984). Stress, appraisal and coping (Springer (ed.)).

Linh, H. G., \& Ngo, T. T. C. (2021). Challenges in learning listening comprehension via Microsoft Teams among English majors at Van Lang University. International Journal of TESOL \& Education, 1(3), 142-175. Retrieved from http://ijte.org/index.php/journal/article/view/36

Long, Đ. M. (2007). Những trở ngại tâm lý trong giao tiếp của sinh viên năm nhất, trường Đại học Sư phạm, Đại học Huế. Tạp Chí Tâm Lý Học, 96(3).

Mahasneh, R. A., Sowan, A. K., \& Nassar, Y. H. (2012). Academic help-seeking in online and face-to-face learning environments. E-Learning and Digital Media, 9(2), 196-210. https://doi.org/10.2304/elea.2012.9.2.196

Maslow, A. H. (1987). Motivation and personality (3rd ed.). Harper \& Row.

McGrath, H., \& Noble, T. (2010). Supporting positive pupil relationships: research to practice. Educational \& Child Psychology, 27(1), 79-90.

Mete, P., \& SubasiI, M. (2020). The Relationship between Academic Coping, Approach Achievement Goals and the Fear of Shame and Embarrassment in Science Class. Journal of Education in Science, Environment and Health, February. https://doi.org/10.21891/jeseh.806463

Murray-Harvey, R. (2010). Relationship influences on students' academic achievement, psychological health and well-being at school. Educational \& Child Psychology, 27(1), 104-115.

Murray-Harvey, R., \& Slee, P. T. (2010). School and home relationships and their impact on school bullying. School Psychology International, 31(3), 271-295.

Nghiem, H. S., Tuyen, L. T. K., Thu, L. N. A., Van, T. Y., \& Thu, P. T. M. (2021). Dificulties when studying away from home. International Journal of TESOL \& Education, 1(1), 112. Retrieved from http://i-jte.org/index.php/journal/article/view/1.

Office, G. S. (2020). Completed results of the 2019 Vietnam population and housing census. Statistical Publishing House.

Pang, L. Van. (2017). The educational experiences of rural Thai ethnic students: 4 case studies. Flinders University.

Phuc, T. H. (2021). University of foreign language studies, the University of Da Nang. University of Foreign Language Studies. http://ufl.udn.vn/eng/introduction/introduction1/introduction.html

Runions, K. C., Pearce, N., \& Cross, D. (2021). How Can Schools Support Whole-school Wellbeing? A Review of the Research. 1-42.

Seidman, I. (2013). Interviewing as qualitative research: a guide for researchers in education and the social sciences. Teachers College Press. 
Streeten, P. (1971). Basic Human Needs. Millennium-Journal of International Studies, 1(1), 29-46. https://doi.org/10.1177/03058298710010010301

Tu, J.-C., \& Chu, K.-H. (2020). Analyzing the Relevance of Peer Relationship, Learning Motivation, and Learning Effectiveness - Design Students as an Example. Sustainability, $12,1-26$.

Tuyen, T. Q., Son, N. H., Huong, V. V., \& Viet, N. Q. (2015). A note on poverty among ethnic minorities in the Northwest region of Vietnam. Post-Communist Economies, 27(2), 268281.

Yin, R. K. (2003). Case study research: design and methods. Sage Publications.

\section{Biodata}

Dr. Lo Van Pang is a senior lecturer of English University of Foreign Language Studies, The University of Da Nang, Vietnam. As a teacher he has taught students from secondary schools to University. He completed his Doctor of Education at Flinders University, Australia in 2017. In terms of academic aspect, he has published several books and papers on English language teaching and education. Dr. Pang used to work as a reviewer for VietTESOL conference and Australian and International Journal of Rural Education. His special interest is in teaching English to students from different cultural backgrounds, special needs, technology in language teaching and cooperative learning. 